\title{
Privileging Oddity and Otherness: A Study of Haruki Murakami's Kafka on the Shore
}

\author{
Rasleena Thakur ${ }^{1}$ and Vani Khurana ${ }^{2}$ \\ ${ }^{1}$ Ph.D. Research Scholar, School of Social Sciences and Languages, Lovely Professional \\ University, Punjab, India.Email: rasleena11o3@gmail.com, ORCID ID: oooo-0oo2-3032-2831 \\ ${ }^{2}$ Assistant Professor, Centre of Professional Enhancement, School of Social Sciences and \\ Languages, Lovely Professional University, Punjab, India.Email: vani.khurana@lpu.co.in
}

\begin{abstract}
The concept of otherness in literature usually comes under the broad purview of postcolonial studies, relating to the subaltern and the displaced. This paper, however, focuses on the concept of the 'other' and the 'odd' in the light of magical realism and how the characters which are generally side-lined by society on the basis of their sexual preference, mental capability, physical deformity, gender fluidity and age find a clear and distinct voice in these fictions. Haruki Murakami's novel Kafka on the Shore is taken up for this study. The unique blend of surrealism (the progenitor genre) with magical realism (the offspring mode) in the novel creates an oneiric landscape which is still very much rooted in reality, in present day Japan. The paper concentrates on the trauma of certain characters and how their exclusion from society leads to their subsequent recovery. The paper through a detailed and critical study of the novel's unusual characters and their non-deterministic status of being typified in traditional categories posits magical realism as an apt literary mode for those who lack a voice and are underrepresented in conventional texts. Here ostracism is not portrayed as pessimistic but as a locus for growth and self-discovery.
\end{abstract}

Keywords: Magical Realism, Murakami, Gender fluidity, Disability, Otherness, Trauma.

\section{Introduction}

In Matthew Carl Strecher's words, "Murakami's use of magical realism, while closely linked with the quest for identity, is not the least bit involved with the assertion of an identity" (Strecher, 1999, p.269). Haruki Murakami doesn't attempt to link his brand of magical realism with the ongoing literary theories of post-colonialism, post-modernism and the various post-isms which decorate the literary arena. He does not try to propound simplistic explanations for his work, but rather leaves them open-ended. As his various novels stand testimony, he writes for a global audience with a profusion of cultures and plenitude of viewpoints. Murakami's fictions revolve around the central questions of identity and the role of history in shaping a person's individuality. Susan J. Napier reiterates the uniqueness of Japan's identity crisis as it was never colonized by Europe and how it remains a unique nation among the non-western nations as it doesn't share the trauma that the colonized non-western nations faced at the hands of the colonizer (Zamora, Lois Parkinson, 1995). Murakami belongs to the post-war generation who have inherited just the haunting memories of war but have not lived through its hypostatized reality. His fictions teeter on the edges of fantastical imagination and politicised history, never reclaiming a definite

(C) AesthetixMS 2020. This Open Access article is published under a Creative Commons Attribution Non-Commercial 4.o International License (http://creativecommons.org/licenses/by-nc/4.o/), which permits non-commercial re-use, distribution, and reproduction in any medium, provided the original work is properly cited. For citation use the DOI. For commercial re-use, please contact editor@rupkatha.com. 
position, inviting various interpretations. The peculiar identity of Japan is reflected in Murakami's idiosyncratic characters, as he writes deceptively simple novels with peculiar characters and themes that are nefariously complex and multi layered. He describes the mundane and the everyday with an extraordinary realism. He is ultimately a master storyteller and his most opportune aim is to recount stories as Wendy B. Faris states "which cater with unidirectional story lines to our basic desire to hear what happens next” (Zamora, Lois Parkinson, 1995, p.163).

Kafka on the Shore (2002) is set in an existent world, in modern day Japan but unexplainable, magical things start happening which provides the novel a 'magical real' bent. The amalgamation of the magical with real does not led to the departure of the text to fantasyland but re-establishes it into the domain of the new real or surreal. The magic does not jar or startle but merges seamlessly into the plot, so much so that it seems like it has grown almost unnoticeably from the real (Zamora, Lois Parkinson, 1995). The world in Kafka on the Shore is marked by an intense loneliness as children are relinquished, solitary odysseys are undertaken and people converse with cats. The theme of identity is ubiquitous as all the characters are grappling with their transient identities in physical and metaphysical worlds. They are misfits as they do not conform to the norm of regular characters in Japanese literary fiction. The novel comprises of an erratic group consisting of a forsaken self-named teenager, a mentally challenged pensioner, a haemophiliac hermaphroditic librarian and a middle-aged reclusive Ikiryo woman. They do not merge in the 'system' but rather exist on the peripheries. Murakami has not described them as being helpless and in need to be assimilated, on the other hand, they are strong, independent characters who have full authority over their otherness. As Andrew Okolie explicates, "Social identities are relational; groups typically define themselves in relations to others. This is because identity has little meaning without the "other". So, by defining itself a group defines others. Identity is rarely claimed or assigned for its own sake" (Okolie, 2003, p.2), these characters have fluid identities as they move seamlessly from the land of the real to the magical without garnering any amazement or analysis from other characters as well as the readers. Everything is accepted as the lines of rational and irrational are seamlessly and continuously crossed over and one is left to question whether such lines truly exist.

\section{Oedipus or Kafka: The Abandoned Adolescent as Other}

Kafka Tamura is the titular character who in order to discover his identity passes through parallel worlds, metaphysical forests and a strange antiquated library. Kafka's real birth name is never revealed through the course of the novel. He baptises himself with a unique name, Kafka, while retaining the surname which links him to his father. By choosing his own name he fosters a distinctive identity for himself. Franz Kafka's literary world is marked by tedious despondency and preponderant nightmares. It is "the 'naturalistic' notation of a fantastic universe, but which the detailed exactitude of the depiction makes real in our eyes, or the unerring audacity of the lurches into the strange" (Flores, 1955, p.189), and it finds an echo in the grave and solemn reality of Murakami's Kafka who also traverses in magical, mystical pathways. As Matthew Carl Strecher puts it one can never be sure whether Murakami's characters lived in a magical world or were simply out of their minds (Strecher, 1999), a predicament similar to the characters of Franz Kafka's oeuvre.

He suffered from a traumatic childhood as his mother left him at the tender age of four and took his elder adopted sister with her. The abandonment left a deep impact on the identity of young Kafka making him alienated and unfit for society. The loss of the mother and neglect of the father led to his creating an 'Other' for himself, an alter ego called "the boy named Crow", his only ally, advisor and accomplice in the world. Kafka means crow in Czech, so the boy named Crow is 
his other more outspoken and worldly wise identity. He has used antonomasia in a process of splitting and calling a part of his repressed self with a different name. The naming process is made evident as instead of simply being called crow, the alter ego is referred as "the boy named Crow". This act of doubling is a characteristic trait of Magical Realism as characters "duplicate themselves in miraculous feats of doubling...images take on lives of their own and engender others beyond themselves" (Zamora, Lois Parkinson, 1995, p.164). At the ambiguous age of fifteen he dangles between childhood and adulthood, while his original reserved self wants to remain shrouded in the cocoon of innocent childhood, his sombre Otherpushes him recklessly towards free will and maturity that comes with adulthood.

\section{Othering of the Disabled: Monster or Man?}

The parallel narrative features a sixty year old illiterate man Nakata who while being considered dim-witted in natural human world, can hold meaningful conversations with cats and make fishes fall from the sky. His disability makes him alienated from society moving him to the realm of otherness. "The physically or mentally impaired person has consistently been used as the "other": the person to who other characters react, emphasizing that someone else is good or evil, or as an excuse for the creation of their own inner world" (Beauchamp, M., Chung, W. V., \& Mogilner, 2010, p.8). While he is not treated badly by anyone, his disability has moved him to the fringes of society. He derives a subsidy from the government in lieu of his disability and earns extra income by finding out missing cats. He leads a simple primitive life where time is ample and there is no need for a watch. He has a limited vocabulary and has never left Nakano ward where he resides. His life is far removed from that of his family which abandoned him as he lacked what they had.

Nakata doesn't tell people that he is illiterate but states he has weak eyesight and hence can't read. He knows that his illiteracy surprises and cautions people so he hides it. Nakata's disability led him to distancing himself from people. As P. Longmore states, "the depiction of the disabled person as "monster" and the criminal characterization both express to varying degrees the notion that disability involves the loss of an essential part of one's humanity. Depending on the extent of the disability, the individual is perceived as more or less subhuman" (Longmore, 1985, p.135), when Otsuka the cat states that Nakata doesn't seem weak-headed Nakata expresses his innate desire to remain the way he is, asserting full recognition of his status of being an Other and how his exclusion has shaped his special identity.

While both Nakata and Kafka identify themselves as others and distance themselves from society, Nakata's otherness is more complex and problematic. Nakata had lost his true identity and independent thought in his childhood during the Rice Bowl Hill incident, a magical event interspersed cleverly by Murakami to extrapolate the gruesome but hidden realities of war. Prior to the Rice Bowl Hill incident, Nakata had been an intelligent child but there were tell-tale signs of him suffering abuse and violence at home. After receiving the unreasonable beating from his class teacher, when he discovered her blood soaked pads, Nakata adopted the defence mechanism of rendering himself completely empty and let himself completely go to the other end, losing all his memories, renouncing his old identity and retaining a new primitive one; an identity void of vocabulary and basic notion of things. To cope with the abuse he faced at home as a normal child, he ended up in complete isolation as a disabled man.

The policeman to whom Nakata confesses his crime doesn't take him seriously, as disabled people are avoided and patronized by the nondisabled. When he makes the prediction of fishes falling from the sky, the policeman laughs it off and his senility is further confirmed in his mind. His odd mannerisms seem endearing and amusing to other people. As L.J. Davis explicates, "an impairment involves a loss or diminution of sight, hearing, mobility, mental ability, and so on. 
But an impairment only becomes a disability when the ambient society creates environments with barriers - affective, sensory, cognitive, or architectural" (Davis, 2002, p.41). The only way Murakami can write a character like Nakata, and through him the people with special needs, and assimilate it into a mainstream story of a wayward teenager is through magical realism. Theo $\mathrm{L}$. D'Haen predicates magical realism as a means for writers to dissociate themselves from discourses of power and speak on the behalf of those who cannot speak for themselves, the excentric and the un-privileged (Zamora, Lois Parkinson, 1995).

\section{Sex versus Gender: The Queer Other}

The erudite librarian Oshima is biologically female but dresses as a male and prefers males but as a male gay person. He (the male pronoun is used as Oshima identifies as male) also suffers from haemophilia which makes her confined and acts as a kind of disability as he cannot partake in risk-taking activities. His complicated odd identity also makes him an Other. When asked by the inquisitive Kafka if he has ever been in love he answers that he is a living, breathing human being, so of course he also has been in love (Murakami, 2006), reasserting the notion that however complicated his identity may be, he is not different. He also have the same universal desires and tendencies which affect all human beings. Oshima tells Kafka about the male/male female/female and male/female divide as explicated by Aristophanes in his The Origin of Love. This is interestingly used by Murakami to explicate the duality of the self and the other, a theory propagated by Simone de Beauvoir in her book The Second Sex. She states, "the category of the Other is as primordial as consciousness itself. In the most primitive societies, in the most ancient mythologies, one finds the expression of a duality - that of the Self and the Other. This duality was not originally attached to the division of the sexes; it was not dependent upon any empirical facts... Otherness is a fundamental category of human thought. (De Beauvoir, 2010).

The scene where two feminists inspect the library and renders it as "lacking fairness" and being "against the principle of gender equality" is effective as when Oshima tries to rationalise with them they accuse him of using his "cheap phallocentric logic" to protect "vested male interests", hence of being discriminatory(Murakami, 2006).

They disagree with everything that doesn't support their point of view. Their prejudice and intolerance against men and inherent identification with traditional male and female roles makes them as ignorant and less aware. Oshima ultimately declares his sexuality which renders them speechless.

My body is physically female, but my mind's completely male...Emotionally I live as a man. So I suppose your notion of being a 'historical example'may be correct. And who knows if I'm a notorious sexist. But I'm not a lesbian, even though I dress this way. My sexual preference is for men. In other words, I'm a female but I'm gay...So, what am I discriminating against?(Murakami, 2006, p.236)

Oshima identifies and is comfortable with his unique hermaphrodite body. He doesn't dwell on the lack but enjoys his status of being a Queer Other. Moreover his haemophilia and sexual preference also blocks out the possibility of reproduction and him having a family, so he takes Kafka under his wing as a sort of son/brother.

\section{The Mother as Ikiryo: Othering of Archetypal Roles}

Miss Saeki is a refined, melancholy woman of middle age who lost herself after her boyfriend's murder during the Students' protests of the late 196os. She also has an Other self in the form of 
her living wandering spirit. Her living spirit wanders in the library in the form of her fifteen year old eternal self and even as her present middle aged self. She can also be called "la mysterique", a concept formulated by Luce Irigaray which signifies "female fluidity and receptivity... the sense of a sensible transcendental coming into being through us, of which we would be the mediators and the bridges" (Faris, 2004, p.212). But the idea more propagated in the text is of an Ikiryo. The living spirit or Ikiryo is a Japanese folkloric concept, introduced inThe Tales of Genji in tenth century Japan. The Ikiryo is described as "the souls of still-living people which have temporarily left their bodies and move about on their own, appearing just as the living person from which they spawn; sometimes they take on a ghostly, translucent form, while other times they are indistinguishable from a living person" ("ikiryo," n.d.). The amalgamation of the myth is an important tenet in magical realist works. The myth of Ikiryo is used cryptically by Murakami to move beyond the barriers set by ordinary reason and to highlight the strength of individual will in all its macabre glory. As Lois Parkinson Zamora postulates,

Ghosts in their many guises abound in magical realist fiction ... they are crucial to any definition of magical realism as a literary mode ... Ghosts embody the fundamental magical realist sense that reality always exceeds our capacities to describe or understand or prove and that the function of literature is to engage this excessive reality, to honor that which we may grasp intuitively but never fully or finally define. (Zamora, Lois Parkinson, 1995, p.498)

The presence of the living spirit in the novel advocates the spirit of the collective spirit which underlines various folklores and mythologies. Kafka also has a living spirit as when Johnnie Walker, who is presumably his father Koichi Tamura, is murdered by Nakata, it is Kafka who loses consciousness and his clothes become blood-soaked. The Ikiryo is roused by the intense hatred he feels for his father and his sordid activities.

Kafka perceives Miss Saeki as her lost mother; however, she neither admits nor denies his perception. For Kafka, his mother is an eternal, unchanging entity, frozen in time when she left him, in essence a young woman who can also be his lover. Kafka fulfils the dual role of the abandoned son of the middle age Saeki and the abandoner boyfriend of the fifteen year old young Saeki; hence, their unique connection enters the domain of a socially taboo relationship. It is not the spirit but the actual flesh and blood Saeki which partakes in the sexual relationship hence mixing dreams with reality. The spirit of Saeki is always silent. Her silence can be perceived as a form of her sexual repression which only finds verbalisation in the other spirit world.

Her dual identity doesn't let her fit into the quotidian role of a mother figure. The archetypal mother figure is selfless and devoted but she is self-serving, sexual and unable to detach from her obsession with the lost past. She commits the taboo of sleeping with her 'supposed' son. As she renounces her earthly life, she stabs a hairpin in her arm and lets Kafka drink her blood in lieu of the milk a mother provides to her offspring. The ritual absolves her and purges Kafka of the toxic blood he has inherited from his father. He accepts the taboo relationship, completes the prophecy and ultimately empathises and forgives her.

\section{Conclusion}

Murakami's works are whimsical, magical and out of the realm of the ordinary. Kafka on the Shore is akin to a winding staircase leading to different and multifarious interpretations, mesmerising its readers with its loose ends and complex portrayals. The issue of othering and oddity on the basis of a person's age, gender, sexual preference and even living or dead status is explicated in great depth throughout the work. All the major characters are not of the norm, odd and peculiar beings that infuse the seemingly ordinary prose with great meaning and greater depth. As 
Matthew Strecher notes in "Magical Realism and the Search for Identity in the Fiction of Murakami Haruki" the characters seek highly individualized and personal sense of identity, in rejection to a national identity which is based on shared beliefs. The marginalization of the disabled and the queer based on mental deficiency and gender identity is cleverly imbued in the coming-of-age tale of an isolated delinquent. The removal of the clearly demarcated boundaries between the mundane and strange provides the work its magical realist stance. It emerges as a favourable mode for the other and the odd as magical realism is in itself a paradox, a lingering enigma. The exclusion which these characters face doesn't push them to the brink of despair but absolves them and acts as a stimulus for their personal growth and recovery.

\section{References}

Beauchamp, M., Chung, W. V., \& Mogilner, A. (2010). Disabled Literature-Disabled Individuals in American Literature. Reflecting Culture (S).

Davis, L. J. (2002). Bending over backwards: Disability, dismodernism, and other difficult positions (Vol. 30). New York: New York University Press.

De Beauvoir, S. (2010). The second sex. Knopf.

Faris, W. B. (2004). Ordinary enchantments: Magical Realism and the Remystification of Narrative.

Flores, A. (1955). Magical realism in Spanish American fiction. Hispania, 38(2), 187-192.

ikiryo. (n.d.). Retrieved from http://yokai.com/ikiryou/

Longmore, P. K. (1985). Screening stereotypes-images of disabled people. Social Policy, 16(1), 31-37.

Murakami, H. (2006). Kafka on the Shore. Vintage.

Okolie, A. C. (2003). Introduction to the Special Issue--Identity: Now You Don't See It; Now You Do. Identity: An International Journal of Theory and Research, 3(1), 1-7.

Strecher, M. C. (1999). Magical realism and the search for identity in the fiction of Murakami Haruki. Journal of Japanese Studies, 263-298.

Zamora, Lois Parkinson, and W. B. F. (1995). Magical Realism: Theory, History, Community. Duke Univ. Press.

Rasleena Thakur is a Research Scholar in the Department of English, School of Social Sciences and Languages at Lovely Professional University, Punjab. Her research concentrates on Magical Realism and Postmodernism.

Dr. Vani Khurana is Assistant Professor and Coordinator of the Department of Verbal Ability in Centre of Professional Enhancement, School of Social Sciences and Languages, at Lovely Professional University. Her research interests include Literature and Psychology and Depersonalization Theory. 